\title{
State of The Art Perselisihan Kontrak Konstruksi di Indonesia
}

\author{
Dede Amar Udi IIma1, Fadia Fitriyanti ${ }^{2}$, Faqih Ma'arifi, ${ }^{3,4}$ Nasrun Baldah $^{5}$, Bambang Utoyo ${ }^{6}$ \\ ${ }^{1}$ Department of International Program for Law and Sharia, Universitas Muhammadiyah-Yogyakarta; \\ ${ }^{2}$ Fakultas Hukum, Universitas Muhammadiyah Yogyakarta, \\ ${ }^{3}$ Jurusan Teknik Sipil dan Perencanaan, FT UNY, \\ ${ }^{4}$ Department of Civil Engineering, Beihang University of Aeronautics and Astronautics (BUAA), \\ ${ }^{5}$ Jurusan Manajemen, Universitas Pelita Bangsa-Bekasi, \\ ${ }^{6}$ PMU Expert, Direktorat Pembelajaran dan Kemahasiswaan, Dikti \\ Email: dede.amar.law17@mail.umy.ac.id
}

\begin{abstract}
ABSTRAK
Paper ini membahas tentang state of the art penyelesaian sengketa konstruksi di Indonesia yang meliputi jenis sengketa, indikasi potensi sengketa, dan perbandingan peraturan penyelesaian sengketa jasa konstruksi. Metode yang digunakan adalah mix method yang terdiri dari expert judgment, studi literatur dengan memperbandingkan riwayat penyelesaian perselisihan kontrak konstruksi mengacu kepada UU No.02/2017, Perpres No.16, UU No. 30 11999, dan PP No. 22/2020, dan Dispute Resolution Management Matrix (DRM-Matrix). Hasil analisis menunjukkan bahwa dua hal pokok penyelesaian sengketa yaitu pilihan penyelesaian sengketa dan penyelesaian sengketa di luar pengadilan (litigasi dan non litigasi). Penyempurnaan diberlakukan dalam PP No.22 Tahun 2020 yang menjelaskan tentang tahapan penyelesaian sengketa yang menyangkut mediasi, konsiliasi, dan arbitrase, juga terkait dengan penunjukkan dewan sengketa.
\end{abstract}

Kata kunci: kontrak, konstruksi, perselisihan, state of the art

\begin{abstract}
This paper discusses of state of the art construction dispute resolution in Indonesia, which includes types of disputes, indications of potential disputes, and comparison of construction service dispute resolution regulations. The proposed method is a mixed-method consisting of expert judgment, literature study by comparing the history of construction contract dispute settlement referring to Law No. 02/2017, Presidential Decree No. 16, Law No. 30/1999, and PP. 22/2020, and the Dispute Resolution Management Matrix (DRM-Matrix). The results show that there are two main issues for dispute resolution, namely the choice of dispute resolution and dispute resolution outside the court (litigation and non-litigation). Improvements are enforced in Government Regulation No.22 of 2020 which explains the stages of dispute resolution involving mediation, conciliation and arbitration, as well as the appointment of a dispute board.
\end{abstract}

Key words: contract, constructions, dispute, state of the art

\section{PENDAHULUAN}

Pembangunan infrastruktur di Indonesia mengalami pencapaian yang signifikan dalam beberapa tahun terakhir. Sumbangsih sektor jasa konstruksi dalam mendukung pertumbuhan ekonomi di Indonesia sangat strategis dan signifikan. Namun, dengan adanya pandemi Covid-19 dalam kurun waktu triwulan kedua pada tahun 2020 mengacu kepada BPS
No.64/08/Th. XXIII, 5 Agustus 2020 mengalami tren penurunan dari Triwulan pertama tahun 2018 sebesar 5.06, puncaknya adalah pada triwulan kedua 2018 (5.27) dan sayangnya pada triwulan kedua tahun 2020 mengalami penurunan signifikan dengan capaian negatif sebesar $(-5.32)$. 
Sedangkan PDB untuk konstruksi sendiri merupakan keempat terbesar setelah bidang industri, perdagangan dan pertanian. Berbagai bidang seperti Sumber Daya Air (SDA), jalan dan jembatan, perumahan hingga pemukiman merupakan proyek strategis nasional dengan anggaran yang cukup besar 75.6 Triliun rupiah.

Pelaksanaan proyek yang mengandung nilai sangat besar tersebut sejalan dengan penyedia jasa yang satu sama lain berkompetisi serta bekerjasama untuk mendapatkan sebuah proyek yang dikehendaki. Bahkan tidak jarang terjadi sengketa (Gambar 1) dalam proses kontrak konstruksi didalamnya yang mencakup sengketa biaya, sengketa waktu, sengketa lingkup pekerjaan, sengketa gabungan antara perubahan biaya, waktu dan lingkup pekerjaan, serta sengketa administrasi.

Perkembangan sengketa konstruksi tidak hanya mencakup beberapa hal diatas, tetapi juga adanya kemungkinan sengketa yang muncul dalam potensi kontrak konstruksi seperti perbedaan peraturan dan dokumen kontrak yang meliputi: ketentuan kontrak lumsump, perubahan harga, denda, dan perpanjangan waktu. Selain itu juga terdapat pelaksanaan pekerjaan yang mencakup: lahan, lingkup pekerjaan, kondisi lapangan, material atau peralatan, personel, dan gambar rencana atau spesifikasi teknis.

Oleh karena itu, Pemerintah telah berupaya melalui kementerian Pekerjaan Umum dan Perumahan Rakyat dengan mengeluarkan Peraturan Menteri PUPR Nomor 14 tahun 2020 dan penjelasannya sebagai revisi dari peraturan perundangan yang berlaku dimulai dari UU No. 30 / 1999 Tentang Arbitrase dan Alternatif Penyelesaian Sengketa, UU No 02 / 2017 Tentang Jasa Konstruksi, Perpres No. 16 Tahun 2018 tentang Pengadaan Barang/ Jasa Pemerintah, dan peraturan yang terbaru PP No. 22/2020 tentang Peraturan Pelaksanan UU No. 2/2017 tentang Jasa Konstruksi.

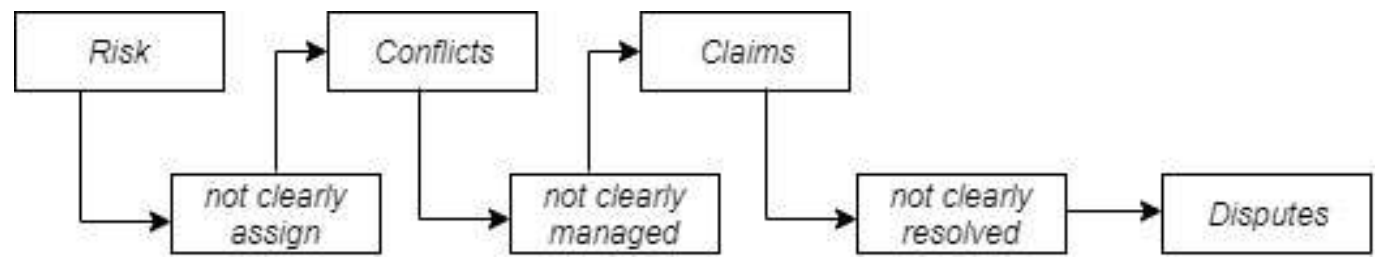

Gambar 1. Riwayat Terjadinya Resiko, Konflik, Klaim, dan Perselisihan (Nirmal, et.,al. 2006)

Solusi yang ditawarkan pemerintah diatas merupakan alternatif dalam berbagai penyelesaian permasalahan kontrak konstruksi di Indonesia dengan merujuk kepada praturan-peraraturan yang berlaku saat ini. Fokus studi ini menitikberatkan pada permasalahan krusial dimana terjadi perselisihan antara pengguna dan penyedia dalam penyelesaian sengketa.

Beberapa referensi yang ada (UU No.30 Tahun 1999), (UU No.2 Tahun 2017), (Perpres No. 16 Tahun 2018), dan (PP No.
22 Tahun 2020) belum mengakomodasi berbagai kepentingan baik pengguna ataupun penyedia, ketika terjadi permasalahan dalam proyek. Melalui peraturan baru, Permen PUPR No.14 tahun 2020 perlu dikaji lebih dalam untuk mengungkap prosedur penyelesaian sengketa.

Mengungkap solusi yang belum pernah ditawarkan oleh peneliti sebelumnya, benang merah standar penyelesaian sengketa kontrak konstruksi merupakan 
salah satu solusi yang ditawarkan, sekaligus menjadi payung hukum bagi pengguna dan penyedia jasa konstruksi jika tahapan yang telah ditempuh untuk penyelesaian sengketa menemui jalan buntu. Hasil kajian ini sekaligus menjadi rekomendasi terkait dengan skema penyelesaian permasalahan konstruksi, hingga tahap akhir yaitu arbitrase.

\section{METODE}

Beberapa metode yang telah dikembangkan dan umum digunakan untuk penyelesaian persilisihan konstruksi diantaranya oleh Min Y.C., et., al. (2009). Sai, O.C. et.,al. (2010), Ghada, et.al. (2011), Castro, J.L. et.,al. (2009), Martineh, et.,al. (2011), Wei, T.C. et.,al. (2010), Zhi, P.F., et,al. (2015), Emre, Sae, H.J. (2012), Pinar (2014) dan Heap. Y.C, and Rosli, M.Z. (2012) yang mana mengusulkan tentang strategi penyelesaian perselisihan meliputi: Fuzzy Case-based reasoning, model persamaan struktural, Logistic Regression (LR), Case-Based Reasoning (CBR), Dispute Resolution Management System Matrix (DRM-Risk Matrix), Analytical Network Process (ANP), Structural Equation Modeling (SEM) dan Factor Analysis Approach (FAP).

Namun demikian, karena keterbatasan cakupan studi kasus, maka metode yang diusulkan dalam paper ini adalah mixed method, yang terdiri dari expert judgment, studi literatur undang-undang dan peraturan pemerintah yang mengatur tentang pengadaan barang dan jasa konstruksi di Indonesia, dan dikombinasikan dengan metode Dispute Resolution Management Matrix (DRMMatrix) yang diusulkan oleh Ghada, et.,al. (2011). Keterbatasan studi ini juga hanya membahas permasalah dari sisi pengguna jasa konstruksi.

Selanjutnya, data tentang perkembangan penyelesaian kontrak konstruksi diperbandingkan, dan dianalisis secara deskriptif untuk menggambarkan kondisi perubahan peraturan dari beberapa tahun sebelumnya. Hasil ini kemudian diperkuat dengan pendapat dari ahli dibidang pengadaan barang dan jasa konstruksi yang bersertifikat resmi dari pemerintah. Identifikasi permasalahan perselisihan konstruksi disajikan kedalam Dispute Resolution Management Matrix (DRMMatrix) untuk mengetahui skala prioritas penyelesaian sengketa konstruksi di Indonesia dibandingkan dengan referensi pendukung Ghada, et.,al. (2011), Sigitas dan Thomas, (2014), Zhi, P.F, et.,al. (2015), Junying, L. et.,al. (2019), Huu, L.N. and Jorma, L.(2011), Junying, L. et.,al. (2017).

\section{HASIL DAN PEMBAHASAN}

Proyek konstruksi di Indonesia merupakan salah satu faktor pendukung pertumbuhan ekonomi di Indonesia bertumbuh dengan pesat, disisi lain tidak terlepas dari adanya sengketa konstruksi yang menyebabkan tidak selesainya sebuah proyek sesuai jadwal yang telah ditetapkan, dalam hal ini penyelesaian sengketa konstruksi dapat diselesaikan melalui 2 jalur, yaitu dengan jalur Litigasi dan Non litigasi, sedangkan untuk faktor penyebab sengketa proyek konstruksi dilaporkan oleh Ghada,et.,al. (2011), Emre and Pinar (2014), Liu et.,al. (2019), Junying et.al., (2019), David, T., et.,al. (2016), Huu, L.N. (2011) tersaji pada Tabel 1. 
State of The... (Dede/ hal 158-170)

Tabel 1. Faktor Penyebab Sengketa Proyek Konstruksi

\begin{tabular}{|c|c|c|}
\hline No & Kategori & keterangan \\
\hline 1 & pengguna jasa & $\begin{array}{l}\text { a. Penundaan pembayaran } \\
\text { b. Penundaan jadwal disebabkan oleh pengguna } \\
\text { c. Perubahan jumlah item selama proyek } \\
\text { d. Cakupan proyek yang ambigu atau perubahan ruang lingkup } \\
\text { proyek atau batasan pekerjaan yang tidak jelas } \\
\text { e. Harapan atau tuntutan yang tidak realistis dan variasi yang } \\
\text { dikeluarkan oleh pengguna selama berlangsungnya proyek } \\
\text { f. Percepatan } \\
\text { g. Kesalahan desain atau kualitas desain yang rendah } \\
\text { h. Informasi yang diberikan oleh pemilik salah / tidak lengkap atau } \\
\text { kurang interpretasi yang wajar } \\
\text { i. Kepemilikan site konstruksi yang terlambat } \\
\text { j. Masalah kualitas } \\
\text { k. Penundaan dalam kemajuan pekerjaan } \\
\text { I. Kegagalan finansial kontraktor }\end{array}$ \\
\hline 2 & penyedia jasa & $\begin{array}{l}\text { a. Ketidaktahuan kondisi geografis proyek } \\
\text { b. Masalah kualitas pekerjaan } \\
\text { c. Penundaan dalam kemajuan pekerjaan } \\
\text { d. Teknisi tidak diberi tahu tentang penundaan waktu atau tim ahli } \\
\text { tidak menyetujui penundaan waktu } \\
\text { e. Kegagalan finansial kontraktor } \\
\text { f. Gagal mendapatkan persetujuan tertulis atas instruksi dari tim ahli } \\
\text { g. Kegagalan untuk sepenuhnya memahami hukum lokal yang } \\
\text { relevan pada saat tender }\end{array}$ \\
\hline
\end{tabular}

3 kontrak konstruksi

a. Interpretasi yang berbeda dari ketentuan kontrak

b. Ketentuan kontrak yang tidak jelas mengenai penyesuaian harga kontrak yang disebabkan oleh jumlah sementara

c. Ketentuan kontrak yang tidak jelas tentang penyesuaian jumlah perkiraan

d. Kondisi pembayaran yang tidak jelas untuk pengembalian uang retensi

e. Metode yang tidak jelas untuk mengurangi kerusakan keterlambatan

f. Definisi dan jenis cacat yang tidak jelas

g. Alokasi risiko yang tidak wajar dalam kontrak

h. Kegagalan untuk mempertimbangkan atau menghitung secara akurat biaya tambahan dari pekerjaan aktual pada saat pelelangan dan perkiraan

i. Kegagalan untuk memeriksa kondisi kontrak pada saat tender

j. Batas tanggung jawab yang ambigu untuk menggunakan atau menyimpan bahan dan peralatan yang disediakan oleh pemberi kerja

k. Ketidaksepakatan mengenai jumlah kompensasi untuk biaya konstruksi dan waktu saat klaim terjadi

I. Ketidaksepakatan metode pembayaran disebabkan oleh variasi kuantitas

4 Faktor eksternal a. Fluktuasi nilai tukar mata uang asing

b. Fluktuasi ekonomi 
State of The... (Dede/ hal 158-170)

\begin{tabular}{ll}
\hline No Kategori & \multicolumn{1}{c}{ keterangan } \\
\hline & c. Pembatasan moneter seperti pembatasan repatriasi dana \\
d. Perubahan hukum dan regulasi \\
e. Sistem hukum tidak sesuai dengan prosedur penyelesaian \\
sengketa dalam kontrak \\
f. Masalah keamanan negara, kendala bahasa, tradisi budaya yang \\
berbeda, dan latar belakang agama \\
g. Force majeure seperti cuaca, perang, revolusi, dan kekacauan sipil \\
h. Perbedaan dalam standar konstruksi, spesifikasi teknis, dan kode, \\
seperti peraturan dan standar untuk praktik konstruksi dan \\
i. Metode konstruksi
\end{tabular}

Berdasarkan Tabel 1 di atas menunjukkan bahwa secara umum terdapat empat faktor yang menyebabkan perselisihan (dispute) diantaranya adalah tinjauan dari (1) pengguna jasa; (2) penyedia jasa; (3) kontrak konstruksi; (4) faktor eksternal. Keempat faktor di atas merupakan salah satu hasil dari pendekatan berbagai faktor perselisihan baik pada standar nasional dan internasional. Pendekatan permasalahan sengketa pada paper ini merujuk pada kategori pengguna jasa dengan menyesuaikan permasalahan di Indonesia.

\section{Litigasi dan Non-Litigasi}

Sengketa melalui litigasi merupakan sarana akhir (Ultimum remidium) setelah alternatif penyelesaian sengketa lain tidak membuahkan hasil. Penyelesaian sengketa ini merupakan jalur penyelesaian sengketa di pengadilan.

Selain penyelesaian sengketa melalui pengadilan (litigasi), penyelesaian sengketa juga dapat diselesaikan diluar pengadilan (non-litigasi). Berdasarkan pasal 6 ayat (1) UU No.30 Tahun 1999 tentang arbitrase dan alternatif penyelesaian sengketa menyatakan bahwa Sengketa atau beda pendapat perdata dapat diselesaikan oleh para pihak melalui alternatif penyelesaian sengketa yang didasarkan pada itikad baik dengan mengesampingkan penyelesaian secara litigasi di Pengadilan Negeri.

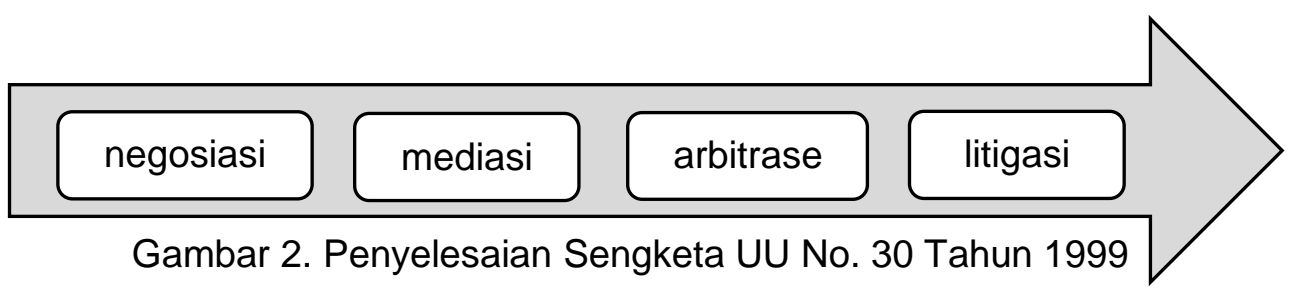

Dari penjelasan UU diatas dapat diketahui bahwa penyelesaian sengketa atau perbedaan pendapat dapat diselesaikan melalui jalur diluar proses peradilan (nonlitigasi). Dalam alternatif ini bertujuan untuk memberikan bantuan hukum dan mencegah terjadinya masalah-masalah hukum yang muncul. Alternatif ini bersifat privat karena umumnya dilakukan kasus perdata. Alternatif ini juga digunakan dalam kontrak internasional yang mengacu pada standar FIDIC (Sang, H.C. dan Yea, S.K. 2015). Proses Analisis Prioritas Faktor risiko sengketa di detailkan berdasarkan kepada studi literatur dan interview expert. Dalam penyelesaian melalui non-litigasi, Indonesia mempunyai badan yang secara khusus menangani permasalahan sengketa konstruksi melalui non-litigasi. Badan Arbitrase Nasional Indonesia (BANI) merupakan badan yang menyediakan jasa berbagai macam penyelesaian sengketa 
melalui arbitrase, mediasi dan bentukbentuk lain dari penyelesaian sengketa di luar pengadilan.

Selain itu, Indonesia juga mempunyai sebuah badan yang secara khusus mengatur tentang penyelesaian sengketa kontrak konstruksi yang dikenal dengan sebutan BADAPSKI (Badan Arbitrase dan Alternatif Penyelesaian Sengketa Kontruksi Indonesia) merupakan badan yang dibentuk untuk menjamin perlindungan hak-hak pengguna jasa dan penyedia jasa.

\section{State of the art penyelesaian sengketa konstruksi}

1. Kajian Undang-Undang No. 30 tahun 1999

Salah satu bentuk sengketa non-litigasi adalah Arbitrase. Penyelesaian ini didasarkan kepada perjanjian yang dibuat secara tertulis dan ditanda tangani oleh kedua belah pihak dengan itikad baik. Sementara bentuk dari putusan arbitrase adalah final dan banding, disisi lain sebuah kesepakatan antara kedua belah pihak (pengguna dan penyedia) berupa klausul arbitrase yang telah termuat dalam perjanjian tertulis yang dibuat oleh para pihak sebelum timbul sengketa atau setelah timbul sengketa.

Undang-undang ini menjelaskan tentang prosedur penyelesaian arbitrase di Indonesia antara lain: prosedur pendaftaran, tahap penunjukan arbiter, tanggapan termohon, tuntutan balik, dan proses sidang bentuk penyelesaian sengketa melalui non litigasi: Negosiasi, Mediasi dan Arbitrase.

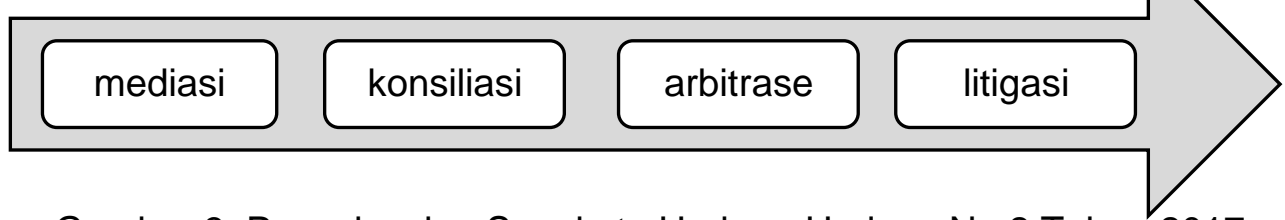

Gambar 3. Penyelesaian Sengketa Undang-Undang No 2 Tahun 2017

2. Kajian Undang-Undang No 2 tahun 2017

Berdasarkan pasal 88 ayat 1 jika terjadi sebuah sengketa konstruksi maka diselesaikan dengan musyawarah, karena undang-undang ini menganut prinsip dasar musyawarah untuk mencapai kemufakatan. Namun apabila para pihak tidak mencapai kemufakatan maka dapat melakukan upaya yang telah tercantum dalam kontrak kerja konstruksi. Apabila upaya penyelesaian sengketa tidak tercantum didalam kontrak kerja konstruksi, maka kedua belah pihak dapat membuat suatu persetujuan tertulis mengenai tata cara penyelesaian sengketa yang akan dipilih.

Adapun tahapan yang dimaksud adalah dengan jalur mediasi, konsiliasi dan arbitrase. Selain itu para pihak juga dapat diperkenankan untuk membentuk dewan sengketa, pembentukan dewan sengketa bisa kita lihat dalam pasal 88 ayat (5) dan (6). Pemilihan anggota dewan sengketa dilakukan berdasarkan prinsip profesionaltias dan tidak menjadi bagian dari salah satu pihak.

Berdasarkan ayat 5 yang dimaksud dengan "dewan sengketa" adalah tim yang dibentuk kesepakatan para pihak sejak pengikatan Jasa Konstruksi untuk mencegah dan menengahi sengketa yang terjadi di dalam pelaksanaan Kontrak Kerja Konstruksi.

3. Kajian Perpres No. 16 tahun 2018

Dalam peraturan ini ketika terjadi sebuah sengketa kontrak kontruksi, maka penyelesainya dapat melalui Lembaga Kebijakan Pengadaan Barang dan Jasa Pemerintah (LKPP). Menurut Perpres No. 16 Tahun 2018, layanan penyelesaian sengketa pengadaan diselenggarakan oleh LKPP cq kedeputian bidang hukum dan 
penyelesaian sanggah. Layanan ini dapat dilaksanakan di domisili LKPP atau tempat lain yang ditetapkan oleh penanggung jawab layanan.

Selanjutnya layanan ini mempunyai fungsi seperti: melaksanakan penanganan dan penyelesaian sengketa pengadaan dengan melalui non-litigasi (arbitrase), melakukan penelitian dan pemeriksaan sengketa pengadaan, dan mendapatkan dokumen atau alat bukti lain guna pemeriksaan berdasarkan peraturan kepala lembaga kebijakan pengadaan barang/jasa pemerintah Nomor 4 tahun 2016 tentang layanan penyelesaian sengketa pengadaan barang/jasa pemerintah, pasal 4 tentang layanan penyelesaian sengketa pengadaan bertugas untuk menangani dan menyelesaikan sengketa pengadaan melalui arbitrase dan pemberian pendapat hukum.

\section{Kajian PP No. 22 Tahun 2020}

Peraturan ini berbeda halnya dengan peraturan sebelumnya, karena penyelesaian sengketa tidak selalu melalui LKPP. Ketika muncul sebuah sengketa kontrak konstruksi terdapat dua cara, yang pertama dengan menggunakan alternatif penyelesaian sengketa atau arbitrase, dan cara yang kedua melalui pengadilan sesuai dengan hukum acara perdata yang berlaku. Pengembangan proses penyelesaian sengketa di atas didukung oleh penelitian yang dilakukan Chaphalkar, N.B., dan Smita, K.P. (2012) yang membuat peta keputusan untuk penyelesaian kontrak, berdasarkan metode Decision Support System (DSS). Dalam metode tersebut dibuatkan sistem pendukung yang kuat untuk memahami dan menyelesaikan sengketa secara administratif atas klausul kontrak. DSS ditetapkan sebagai upaya untuk mencegah terjadinya penyelesaian satu pintu. Jalur Arbritase lebih ditekankan dalam analisisnya, dibandingkan dengan jalur litigasi.
Lebih lanjut dalam hal ini bentuk putusanya final dan mengikat para pihak untuk dilaksanakan dengan itikad baik. Jadi, perubahan peraturan perundangundangan terus dilakukan oleh pemerintah sebagai upaya untuk melindungi hak dan kewajiban pengguna dan penyedia jasa dalam melakukan aktivitas proyek konstruksi di Indonesia.

\section{Telaah khusus Permen PUPR No. 14 Tahun 2020}

Di dalam peraturan Menteri PUPR No.14 tahun 2020 telah disampaikan terkait dengan detail penyelesaian perselisihan, yang mana merupakan perbaikan dari peraturan sebelumnya. Adapun item yang dibahas terkait dengan:

\section{Sengketa Biaya (Fee Dispute)}

Keterlambatan pembayaran owner kepada kontraktor merupakan salah satu penyebab keterlambatan proyek. Kontraktor berhak untuk mengajukan klaim dan menerima kompensasi akibat dari keterlambatan yang diakibatkan oleh owner, keterlambatan ini biasa dikenal dengan Excusable Compensable Delays.

Keterlambatan ini akan berakibat terhadap menurunnya kinerja kontraktor dan proyek dapat berhenti karena dampak dari keterlambatan pembayaran tersebut bisa menimbulkan keuangan kontraktor tidak sehat. Disisi lain, kontraktor juga akan menunda pembayaran kepada subkontraktor untuk mengurangi beban keuangan. Jika keterlambatan ini berlangsung lama, dan sub-kontraktor tidak memiliki modal yang cukup besar, maka akan mengakibatkan kerugian pada subkontraktor bahkan sampai dengan bangkrut.

Selain dari aspek pembiayaan, harga satuan pekerjaan juga sangat penting untuk meningkatkan pembangunan proyek kontruksi yang baik. Dalam membangun proyek kontruksi perlu adanya laporan dari 
pengguna jasa, dan barang-barang apa saja yang diperlukan untuk pembangunan. Selain itu, faktor pendorong yang membuat proyek kontruksi dapat berjalan karena didukung oleh para pekerja yang mengerjakan proyek tersebut. Para pekerja ini mendapatkan angsuran pembayaran seperti yang tertuang di dalam isi kontrak, namun sengketa bisa muncul jika saat jatuh tempo para pekerja mendapatkan angsuran pembayaran ternyata tidak sama sekali.
2. Sengketa waktu (time Dispute)

Waktu merupakan aspek yang sangat penting dalam penyelesaian proyek kontruksi, karena pengguna jasa memerlukan bangunan untuk kepentingan tertentu, waktu penyelesaian pekerjaan ini tentunya sudah ditetapkan dengan baik, hal ini berfungsi agar tidak terjadi sebuah permasalahan atau sengketa proyek kontruksi karena tidak sesuai dengan isi kontrak.

Tabel 2. Analisis DRM- Matrix

\begin{tabular}{|c|c|c|c|c|c|c|c|}
\hline $\begin{array}{l}\text { Kategori } \\
\text { resiko }\end{array}$ & Resiko & item terkait & Musyawarah & Mediasi & Konsiliasi & Arbitrase & Litigas \\
\hline \multirow{11}{*}{$\begin{array}{l}\text { Pengguna } \\
\text { jasa }\end{array}$} & Biaya & 1. Penundaan & $\sqrt{ }$ & $\sqrt{ }$ & $\sqrt{ }$ & $\mathrm{x}$ & $\mathrm{x}$ \\
\hline & & $\begin{array}{l}\text { 2. Harga } \\
\text { satuan } \\
\text { pekerjaan }\end{array}$ & $\sqrt{ }$ & $\sqrt{ }$ & $\sqrt{ }$ & $x$ & $x$ \\
\hline & & $\begin{array}{l}\text { 3. Nilai } \\
\text { angsuran } \\
\text { pembayaran }\end{array}$ & $\sqrt{ }$ & $\sqrt{ }$ & $\sqrt{ }$ & $x$ & $x$ \\
\hline & Waktu & $\begin{array}{l}\text { 1. Penundaan } \\
\text { jadwal } \\
\text { proyek }\end{array}$ & $\sqrt{ }$ & $\sqrt{ }$ & $\sqrt{ }$ & $x$ & $x$ \\
\hline & & 2. Percepatan & $\sqrt{ }$ & $\sqrt{ }$ & $\sqrt{ }$ & $\mathrm{x}$ & $x$ \\
\hline & $\begin{array}{l}\text { Lingkup } \\
\text { pekerjaan }\end{array}$ & $\begin{array}{l}\text { 1. Jenis } \\
\text { pekerjaan }\end{array}$ & $\sqrt{ }$ & $\sqrt{ }$ & $\sqrt{ }$ & $x$ & $\mathrm{x}$ \\
\hline & & 2. Volume & $\sqrt{ }$ & $\sqrt{ }$ & $\sqrt{ }$ & $\mathrm{x}$ & $x$ \\
\hline & & 3. Mutu/kualitas & $\sqrt{ }$ & $\sqrt{ }$ & $\sqrt{ }$ & $\sqrt{ }$ & $\sqrt{ }$ \\
\hline & Administrasi & 1. PPK & $\sqrt{ }$ & $\sqrt{ }$ & $\sqrt{ }$ & $\mathrm{x}$ & $\mathrm{x}$ \\
\hline & & 2. Penyedia & $\sqrt{ }$ & $\sqrt{ }$ & $\sqrt{ }$ & $\mathrm{x}$ & $\mathrm{x}$ \\
\hline & & 3. Wakil sah & $\sqrt{ }$ & $\sqrt{ }$ & $\sqrt{ }$ & $\mathrm{x}$ & $\mathrm{x}$ \\
\hline
\end{tabular}

Faktor cuaca merupakan salah satu yang dapat mempengaruhi penyelesaian pekerjaan tepat waktu. Pengenaan denda oleh pengguna jasa akibat keterlambatan penyelesaian pekerjaan kontruksi disebabkan karena kesalahan pelaksana konstruksi. Pengenaan denda ini jumlahnya sesuai dengan lamanya keterlambatan dengan batas maksimal denda tertentu.

\section{Sengketa Lingkup Pekerjaan (work scope disputes)}

Suatu proyek kontruksi tentunya membutuhnkan sumber daya manusia dalam setiap pelaksanaanya, tidak semua pekerja dapat di proyek besar seperti jalan tol, para pekerja harus mempunyai mutu atau yang berstandar sertifikasi. Hal ini agar proyek yang dikerjakan dapat berjalan dengan baik dan menghasilkan proyek berkualitas baik sesuai dengan standar mutu yang telah ditetapkan.

\section{Sengketa Gabungan}

Sengketa gabungan yang dimaksud adalah terkait dengan perubahan biaya, waktu dan lingkup pekerjaan pada proyek konstruksi, diantaranya adalah sebagai berikut:

a. Perubahan Biaya dan waktu (Changes in fees and times)

Mengingat biaya dan waktu merupakan suatu hal yang sangat berkaitan, maka dari 
itu pembangunan perlu diselesaikan dengan cepat sesuai dengan waktu yang telah ditetapkan sebelumnya. Walaupun biaya yang sudah dikeluarkan cukup banyak namun apabila pembangunanya tidak tepat waktu maka akan menimbulkan sengketa konstruksi karena tidak sesuai dengan isi kontrak.

b. Biaya dan lingkup pekerjaan (Costs and scope of work)

Perubahan biaya yang terjadi ketika proyek kontruksi akan mengambat pembangunan, karena pada kontrak sebelumnya sudah ditetapkan biaya awalnya, hal ini dapat menimbulkan sengketa karena tidak sesuai dengan isi kontrak.

c. Waktu dan lingkup pekerjaan (Time and scope of work)

Dalam proyek kontruksi waktu merupakan hal yang sangat penting karena dengan selesainya pembangunan yang tepat waktu maka akan berdampak baik pada lingkup pekerjaan, salah satunya pembiayaan untuk para pekerja tepat waktu.

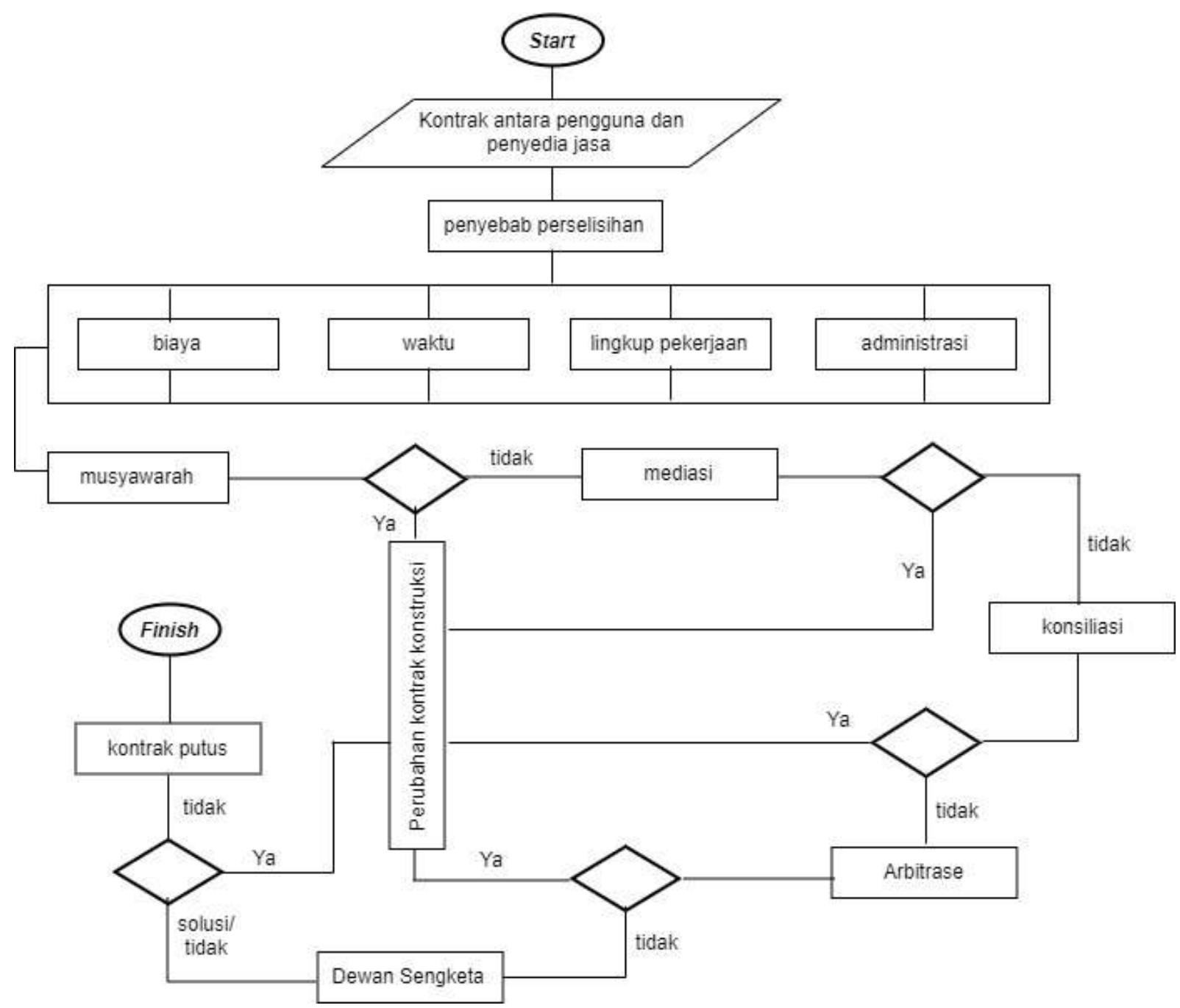

Gambar 4. Model Proses Penyelesaian Sengketa Modifikasi

d. Biaya, waktu, dan lingkup pekerjaan (Cost, time and scope of work)

Ketiga elemen tersebut sangat berkaitan dalam sebuah proyek konstruksi, waktu dan biaya haruslah sesuai dengan isi kontrak yang telah disepakati, dengan selesaianya sebuah pembangunan maka berdampak pada lingkup pekerjaan. 


\section{e. Sengketa Administrasi (Administrative Dispute)}

Sebelum suatu proyek dilaksanakan, perlu perencanaan anggaran yang jelas dan lengkap. Jika belum jelas dan tuntas pada tahap ini, maka akan dapat menimbulkan sengketa proyek konstruksi pada saat proyek berjalan. Selain itu, dari semua tahapan perencanaan hingga proyek selesai, harus dibuat sebuah laporan. Hal ini bertujuan untuk memastikan apakah dana yang direncanakan dapat digunakan dengan benar dan sesuai rencana atau tidak.

Permasalahan di atas tidak hanya terjadi di Indonesia, dalam studi yang dilakukan oleh Yildizel, S.A. et.,al. (2017) di Turki juga menyebutkan setidaknya ada empat hal penting yang menyebabkan sering terjadinya perselisihan meliputi: (1) kualitas pekerjaan yang rendah; (2) keterlambatan pembayaran oleh owner; (3) kurangnya profesionalitas project management consultant; (4) dokumen kontrak yang buruk; (5) dan kesalahan desain.

Dalam Permen PUPR No. 14 tahun 2020 disebutkan bahwa sengketa konstruksi dapat muncul karena keterlambatan pembayaran, keterlambatan penyelesaian pekerjaan, ketidakmampuan baik teknis maupun manajerial dari para pihak, dan perbedaan penafsiran dokumen, selain itu sengketa kontruksi dapat timbul jika pengguna jasa tidak melaksanakan tugas dan kewajibanya dengan baik atau mungkin tidak memiliki dukungan dana yang cukup.

Penyelesaian sengketa melalui jalur diluar pengadilan merupkan penyelesaian yang dianggap efekif, salah satunya melalui jalur arbitarse yang lebih diutamakan oleh pelaku bisnis nasional atau internasional, karena dinilai lebih cepat, murah, sederhana, dan menerapkan perinsip win-win solution. Proses persidangan arbitrase sifatnya tertutup sehingga tidak diketahui oleh umum, yang sifatnya final dan mengikat. Pendekatan penyelesaian ini juga dilaporkan oleh Ghada, et.al. (2016) yang menyatakan bahwa pendekatan non-litigasi dengan metode DRM memiliki tingkat kepercayaan lebih tinggi dibandingkan dengan yang lainnya. Meskipun dalam temuan selanjutnya dijelaskan tentang salah satu item yang perlu dipertimbangkan yaitu faktor sosial yang ternyata juga berpengaruh terhadap permasalahan perselisihan. Jika merujuk di dalam Permen PUPR, item ini juga belum sepenuhnya dibahas sebagai salah satu factor penyebab perselesihan, meskipun dalam pendekatannya dapat digunakan dengan metode musyawarah.

\section{Prosedur penyelesaian sengketa (Permen PUPR)}

Dalam setiap kegiatan proyek kontruksi memang sangat rentan terhadap sengketa yang terjadi, sengketa kontrak konstruksi dapat diselesaikan melalui berbagai cara, seperti dengan cara litigasi ataupun non litigasi. Namun demikian banyak pengusaha memilih penyelesaian sengketa dengan jalur non-litigasi. Pemilihan jalur ini dinilai lebih murah, cepat, dan sederhana.

Prosedur penyelesaian sengketa telah di atur di dalam Permen No 14 tahun 2020 seperti disajikan pada Gambar 4 dengan usulan pada item pasca arbitrase menurut pendapat ahli. Berdasarkan peraturan ini terdapat prosedur untuk menyelesaikan sengketa. Prosedur pertama yang harus dilalui yaitu melakukan musyawarah yang mana para pihak wajib berupaya sungguhsungguh menyelesaikan secara damai semua perselisihan.

Apabila tercapai kesepakatan, maka akan ada perubahan kontrak konstruksi. Namun jika belum tercapai titik terang, tahapan yang dapat ditempuh selanjutnya adalah mediasi. Mediasi merupakan upaya penyelesaian sengketa dengan melibatkan pihak ketiga yang disebut dengan mediator (Guohong, H.H., dan Harms, P.D. 2010). Pihak ketiga ini tentunya harus netral, dalam 
mediasi ini mediator tidak mempunyai wewenang untuk mengambil atau memaksakan keputusan, altrenatif ini dikenal seperti musyawarah dimana keputusan akhirnya tergantung kepada kedua belah pihak, Namun apabila cara ini masih belum menemukan jalan keluarnya, maka para pihak dapat menyelesaikan sengketanya dengan cara konsiliasi.

Konsiliasi merupakan upaya penyelesaian sengketa diluar pengadilan dengan melalui perundingan kedua belah pihak untuk mencapai kesepkatan dengan dibantu konsiliator, selain itu para pihak juga dapat diperkenankan untuk membentuk dewan sengketa. Pembentukan dewan sengketa bisa kita lihat Permen No 14 tahun 2020. Pemilihan anggota dewan sengketa dilakukan berdasarkan prinsip profesionalitas dan tidak menjadi bagian dari salah satu pihak. Jika semua tahapan menemui jalan buntu, maka solusi terakhir dengan menggunakan jalur Arbitrase.

Merujuk kepada Pasal 1 Nomor 1 UndangUndang Nomor 30 Tahun 1999 tentang Arbitrase dan Alternatif Penyelesaian Sengketa, arbitrase diartikan sebagai suatu cara penyelesaian sengketa perdata di luar peradilan umum yang didasarkan pada perjanjian arbitrase yang dibuat secara tertulis oleh para pihak yang bersengketa. Adapun prosedur mengenai penyelesaian arbitrase di Indonesaia antara lain: prosedur pendaftaran, tahap penunjukan arbiter, tanggapan termohon, tuntutan balik, dan proses sidang pemeriksaan. Bentuk dari putusan arbitrase adalah final dan banding. Namun demikian, Jalan yang ditempuh melalui Arbitrase bukannya tanpa celah. Seperti dijelaskan dalam Gambar 4, apabila salah satu pihak menyatakan keberatan, maka ditunjuk dewan sengketa untuk menyelesaikan perselisihan antara pengguna dan penyedia jasa konstruksi. Jika keputusan dewan sengketa dimenangkan oleh pengguna jasa ataupun sebaliknya, selanjutnya dapat dilakukan pilihan untuk memenuhi tuntutan yang dimaksud dengan memperbarui dokumen kontrak konstruksi. Namun demikian, jika tidak juga terjadi kesepakatan yang baik antara kedua pihak, ada pilihan lain yang dianggap sebagai jalan keluar akhir yaitu pemutusan kontrak dengan tetap memenuhi tuntutan yang telah ditentukan oleh pengguna jasa konstruksi.

\section{SIMPULAN}

Peraturan Menteri PUPR No. 14 tahun 2020 lebih menitikberatkan kepada aspek nonlitigasi, karena jalur litigasi cenderung akan menghabiskan waktu dan biaya, baik dari pengguna dan penyedia. Peraturan ini juga mengakomodasi kepentingan dari kedua belah pihak jika terjadi sengketa. Perbaikan signifikan dalam peraturan ini terdapat pada bagian yang mengedepankan musyawarah, mediasi dan konsiliasi, dibandingkan dengan arbitrase.

\section{DAFTAR RUJUKAN}

Badan Pusat Statistik. 2020. No.64/08/Th. XXIII, tanggal 05 Agustus 2020. https://www.bps.go.id/pressrelease/2020/08/05/272/berita-resmistatistik.html. Diakses pada 14 November 2020.

Castro, J.L. et.,al. 2009. Loss and gain functions for CBR retrieval. Information Sciences. Vol. 179. Hal. 1738-1750.

Chaphalkar, N.B., dan Smita, K.P. 2012. Decision Support System for Dispute Resolution in Construction Contracts. KSCE Journal of Civil Engineering. Vol. 16(4). Hal. 499-504.

David, T., et.,al. 2016. Construction Disputes in Small to Medium Enterprise's in Ireland During Recession Identification of Critical Factors. International Journal of Law in the Built Environment. Vol. 8 No. 1. Hal. 21-41. 
Emre, C., Pinar, I.C., 2014. An Analysis Of Causes Of Disputes In The Construction Industry using Analytical Network Process, Procedia Soc. Behav. Sci. Vol. 109 (5). Hal. 183187.

Ghada, et.,al. 2010. Effect of Culture on Selection of Dispute Resolution Methods in International Contracts. Construction Research Congress. ASCEE. Hal. 909-918.

Ghada, et.al. 2016. Strong, Rethinking Trust in Construction Contract Formation: Dispute Resolution Method Selection, J. Leg. Aff. Disput. Resolut. Eng. Constr. Vol. 8 (3). Hal. 04516003 (110).

Ghada, et.,al. 2011. Analytical Framework for the Choice of Dispute Resolution Methods in International Construction Projects Based on Risk Factors. J. Leg. Aff. Disput. Resolut. Eng. Constr. Vol. 3(2). Hal. 79-85.

Guohong, H.H., dan Harms, P.D. 2010. Team Identification, Trust and Conflict: A Mediation Model. International Journal of Conflict Management. Vol. (21), No. 1. Hal. 20-43.

Heap. Y.C, and Rosli, M.Z. 2012. Selection of Dispute Resolution Methods: Factor Analysis Approach, Engineering, Construction and Architectural Management. Vol (19) No. 4. Hal. 428-443.

Huu, L.N. and Jorma, L. 2011. Determinants of Conflict Management Strategies in International Joint Ventures: An Integrative Theoretical Framework. Journal of Transnational Management. Vol 16. Hal. 116-132.

Huu, L.N. 2011. Partnership Strategies: Proactive and Pre-active Approach in
Conflict Management in International Joint Ventures. International Journal of Business and Management. Vol. 6(9). Hal. 38-45.

Junying, L., et.al. 2019. Experience Mining Based on Case-based Reasoning for Dispute Settlement of International Construction Projects. Automation in Construction. Vol. 97. Hal. 181-191.

Junying, L. et.,al. 2017. Improving Risk Assessment in Financial Feasibility of International Engineering Projects: $A$ Risk Driver Perspective. International Journal of Project Management. Vol 35. Hal.204-211.

Martineh, E.,et.al, 2011. Identification of Risk Paths in International Construction Projects Using Structural Equation Modeling, Journal of Construction Engineering Management. Vol. 137 (12). Hal. 1164-1175.

Min, Y.C. 2009. Fuzzy Case-Based Reasoning for Coping with Construction Disputes. Expert Systems with Applications. Vol (36), No. (2). Hal. 4106-4113.

Nirmal, K.A., et.,al. 2006. Conflicting Factors in Construction Projects: Korean perspective. Engineering, Construction and Architectural Management, Vol. 13 No. 6, 2006. Hal 543-566.

Peraturan Presiden Nomor 16 Tahun 2018 tentang Pengadaan Barang/ Jasa Pemerintah

PP No. 22 Tahun 2020 tentang Peraturan Pelaksanan UU No. 2 Tahun 2017 tentang Jasa Konstruksi.

Peraturan Menteri Pekerjan Umum dan Perumahan Rakyat No. 14 Tahun 2020 tentang Standar dan Pedoman 
Pengadaan Konstruksi Melalui Penyedia.

Sai, O.C. et.,al. 2010. Exploring the Potential for Predicting Project Dispute Resolution Satisfaction Using Logistic Regression. Journal of Construction Engineering and Management. Vol. 136. Hal.508-517.

Sae, H.J. 2012. Case Adaptation Method of Case-Based Reasoning for Construction Cost Estimation in Korea. Journal of Construction Engineering Management. Vol. 138. Hal. 43-52.

Sigitas M, dan Thomas M. 2014. Causes of Conflicts in a Construction Industry: A Communicational Approach. Procedia - Social and Behavioral Sciences. Vol.110. Hal. 777-786.

Sang, H.C. dan Yea, S.K. 2015. Priority Analysis of Dispute Factors in Overseas Construction Based on FIDIC Contract Conditions. KSCE Journal of Civil Engineering (0000) 00(0). Hal. 1-10.

Undang-Undang Nomor 30 Tahun 1999 Tentang Arbitrase dan Alternatif Penyelesaian Sengketa

Undang-Undang Nomor 02 Tahun 2017 Tentang Jasa Konstruksi
Wei, T.C. et.,al. 2010. Developing a CBRBased Adjudication System for Fatal Construction Industry Occupational Accidents. Part I: Building the System Framework. Expert Systems with Applications. Vol. 37. Hal. 4867-4880.

Yildizel, S.A. et.,al. .2017. Major Constructional Dispute Causes in Turkey, Archives of Civil Engineering. Vol 2 (4). Hal. 193-204.

Zhi P. F., Yong, H.L, and Yao, Z., 2015. Generating Project Risk Response Strategies Based on CBR: A case Study. Expert System with Applications. Vol. 42 (6). Hal. 28702883. 